\title{
PENGARUH TINGKAT PENDIDIKAN, PELATIHAN DAN BUDAYA ORGANISASI TERHADAP KINERJA PEGAWAI RUMAH SAKIT BHAYANGKARA KENDARI
}

\author{
Fitri Lapau ${ }^{1)}$, Waode Maratun Shaleha ${ }^{2)}$ Al Asy Ari Adnan Hakim ${ }^{3}$ \\ ${ }^{1)}$ Fakultas Ekonomi dan Bisnis Islam, Universitas Muhammadiyah Kendari \\ e-mail: lapaufitri@gmail.com \\ Fakultas Ekonomi dan Bisnis Islam, Universitas Muhammadiyah Kendari \\ e-mail: wdmaratunshaleha@febi.umkendari.ac.id \\ ${ }^{3)}$ Fakultas Ekonomi dan Bisnis Islam, Universitas Muhammadiyah Kendari \\ e-mail: alasyariadnanhakim@febi.umkendari.ac.id
}

\begin{abstract}
Abstrak
Penelitian ini bertujuan untuk menganalisis secara parsial apakah variabel tingkat Pendidikan, pelatihan, dan budaya organisasi memiliki pengaruh yang signifikan terhadap kinerja pegawai, dan menganalisis secara simultan apakah variabel tingkat Pendidikan, pelatihan, dan budaya organisasi memiliki pengaruh yang signifikan terhadap kinerja pegawai. Jenis penelitian yang digunakan dalam penelitian ini adalah pendekatan kuantitatif. Jumlah sampel dalam penelitian ini berjumlah 129 responden pegawai yang bekerja di rumah Sakit Bhayangkara Kendari. Alat analisis yang digunakan dalam penelitian ini adalah analisis regresi linear berganda. Hasil penelitian ini menunjukkan bahwa terdapat adanya pengaruh positif signifikan antara pelatihan dan budaya organisasi terhadap kinerja pegawai Rumah Sakit Bhayangkara Kendari, pendidikan memiliki pengaruh positif tidak signifikan terhadap kinerja pegawai, terdapat hubungan positif signifikan antara pelatihan terhadap kinerja pegawai, terdapat hubungan positif signifikan antara budaya organisasi terhadap kinerja pegawai, untuk variabel pendidikan ditemukan bahwa terdapat pengaruh positif tidak signifikan terhadap kinerja pegawai.
\end{abstract}

Keywords: tingkat Pendidikan, pelatihan, budaya organisasi, kinerja pegawai

\begin{abstract}
This study aims to partially analyze variables of education level, training, and organizational culture have a significant effect on employee performance, and simultaneously analyze variables of education, training, and organizational culture have a significant effect on employee performance. Type of research is a quantitative approach. Samples in this study amounted to 129 employee respondents who worked at the Bhayangkara Kendari Hospital. The analytical tool used in this research is multiple linear regression analysis. The results of this study indicate that there is a significant positive effect between training and organizational culture on employee performance at Bhayangkara Kendari Hospital, education has a positive and insignificant effect on employee performance, there is a significant positive relationship between training and employee performance, there is a significant positive relationship between organizational
\end{abstract}


culture. on employee performance, for the education variable it was found that there was a positive and insignificant effect on employee performance.

Keywords: level of education, training, organizational culture, employee performance

\section{PENDAHULUAN}

Pegawai Negeri Sipil berkedudukan sebagai unsur aparatur negara yang bertugas untuk memberikan pelayanan kepada masyarakat secara profesional,jujur, adil, dan merata dalam penyelenggaraan tugas negara, pemerintahan dan pembangunan (Suradji, 2006). Untuk memberikan pelayanan yang prima maka suatu instansi harus di dukungdengan sumber daya manusia yang berkualitas. Kinerja adalah suatu hasil dimana orang-orang dan sumberdaya lain yang ada dalam organisasi secara bersama-sama membawa hasil akhir yang didasarkan pada tingkat mutu dan standar yang telah ditetapkan maka konseksuensinya, organisasi memerlukan sumber daya manusia yang memiliki keahlian dan kemampuan yang unik yang sesuai dengan visi dan misi organisasi, (Vonderemse, 2003).

Kinerja dipandang sebagai pelaksanaan dari suatu tindakan atau kemampuan seseorang. Kinerja yang baik juga terkait dengan pencapaian kualitas, kuantitas, kerjasama, kehandalan dan kreativitas. Kinerja karyawan dianggap sebagai ukuran kualitas sumber daya manusia yang dimiliki oleh organisasi. Menurut Churchill, Ford danWalker (1987) bahwa Kualitas pegawai berpengaruh penting terhadap kinerja. Untuk meningkatkan kualitas pegawai maka dapat ditempuh dengan berbagai cara diantaranya melalui pendidikan dan pelatihan yang diperoleh baik secara formal ataupun non formal.

Kesesuaian pendidikan terhadap pekerjaan dapat meningkatkan kinerja pegawai, pegawai telah mendapatkan pengetahuan dari proses pendidikan yang telah diperolehnya sehingga seorang pegawai tersebut memiliki daya tanggap dan kreativitas yang baik dalam memecahkan masalah pekerjaan yang dihadapinya. Menurut Blundel et al (1999) bahwa tingkat pendidikan akan bermanfaat bagi banyak organisasi, tingkat pendidikan merupakan suatu prasarat bagi organisasi dalam melakukan suatu perekrutan. Selanjutnya Thomas \& Fieldman (2009) menyatakan bahwa pegawai yang memiliki pendidikan yang tinggi memiliki hasil kerja yang melampaui tugas pokoknya, namun imbalan yang diperoleh harus sebanding dengan hasil kerja yang dicapai. Ini berarti bahwa pendidikan mempunyai keterkaitan 
langsung dengan kinerja pegawai. Hal ini telah dibuktikan oleh Letmair \& Nehls (2011) tingkat pendidikan berpengaruh positif dan signifikan terhadap kinerja pegawai, sedangkan Patrick (2008) menemukan bahwa tingkat pendidikan tidak berpengaruh signifikan terhadap kinerja.

Mincer, (1962) dan Becker (1962) menyatakan bahwa pendidikan dan pelatihan memberikan manfaat untuk meningkatkan produktivitas pegawai yang lebih tinggi, keterampilan dan kompetensi yang diperoleh dalam pendidikan dapat digunakan dibeberapa organisasi, sedangkan pelatihan khusus dapat memberikan kompetensi bagi organisasi tertentu. Ini berarti pelatihan bagi pegawai merupakan sebuah proses mengajarkan pengetahuan, keahlian tertentu, sikap dan mampu melaksanakan tanggung jawab yangdiberikan. Pelatihan merupakan kegiatan penting untuk pengelolaan sumber daya manusia dalam organisasi apapun, pelatihan dapat didefinisikan sebagai proses melalui mana perubahan perilaku, pengetahuan dan motivasi karyawan dapat dicapai dalam rangka meningkatkan kompatibilitas antara karakteristik dan kemampuan karyawan dan persyaratan kerja. (Dora \&Sabag, 2008). Menurut Hasnizah ( 2009 ) pelatihan membantu orang untuk belajar bagaimana menjadi lebih efektif di tempat kerja dengan memodifikasi pengetahuan, keterampilan atau sikap melalui pengalaman belajar untuk mencapai kinerja yang efektif. Ini berarti bahwa pelatihan memiliki korelasi terhadap pencapaian kinerja pegawai.

Hubungan antara konsep pelatihan dengan kinerja pegawai telah dibuktikan oleh Anam et al (2013); Diabi \& Ajlouni (2015) bahwa, pelatihan berpengaruh positif dan signifikan terhadap kinerja karyawan, sedangkan Papahan et al (2014) menemukan bahwa, pelatihan tidak berpengaruh signifikan terhadap kinerja. Selain faktor pendidikan dan pelatihan yang menentukan kinerja pegawai maka faktor lingkungan kerja terutaman yang berhubungan dengan sistem tata nilai, kebiasaan maupun norma - norma yang berlaku dalam suatu organisasi tidak terkecuali pada usaha Rumah Sakit. Nilai-nilai tersebut telah menjadi pegangan bagi semua pihak yang terlibat dalam kegiatan usaha tersebut. Faktor sistem nilai, kebiasaan maupun norma-norma yang berlaku dalam suatu organisasi disebut dengan istilah budaya organisasi.

Budaya organisasi adalah seperangkat asumsi atau sistem keyakinan, nilai-nilai, dan norma yang dikembangkan dalam organisasi yang dijadikan pedoman tingkah laku bagi 
anggota-anggotanya untuk mengatasi masalah adaptasi eksternal dan internal (Mangkunegara, 2005). Menurut Robbins, (1996) bahwa, fungsi budaya organisasi sebagai berikut:(1) budaya menciptakan pembedaan yang jelas antara satu organisasi dan yang lain, (2) budaya membawa suatu rasa identitas bagi anggota-anggota organisasi, (3) budaya mempermudah timbulnya komitmen pada sesuatu yang lebih luas daripada kepentingan individual, (4) budaya merupakan perekat sosial yang membantu memersatukan organisasi itu dengan memberikan standar-standar yang tepat untuk dilakukan oleh karyawan, dan (5) budaya sebagai mekanisme pembuat makna dan kendali yang memandu dan membentuk sikap serta perilaku karyawan.

Budaya organisasi adalah kerangka kerja yang menjadi pedoman dan landasan bagi semua pihak yang terlibat organisasi dalam melaksanakan semua aktivitas yang berkaitan dengan tugas dan tanggungjawab yang dibebankan kepada pegawai. Sistem tata nilai, kebiasaan-kebiasaan rutin maupun norma-norma yang telah ditetapkan oleh organisasi, seharusnya menjadi landasan bagi setiap pegawai dalam melaksanakan tugasnya sehingga setiap pegawai memiliki komitmen yang tinggi untuk melaksanakan nilai-nilai budaya organisasi tersebut. Misalnya, setiap pegawai senantiasa memiliki semangat inovasi dengan tetap mempertimbangkan kemugkinan resiko yang timbul, kemudian dalam melaksanakan tugas dan pekerjaan hendaknya selalu berorientasi terhadap tugas yang sedang dijalankan dan diselesaikan secara tuntas dan terinci. Nilai- nilai tersebut merupakan bagian dari budaya organisasi, dalam realitasnya belum sepenuhnya dapat dijalankan oleh semua pihak yang terlibat dalam organisasi termasuk rumah sakit Bhayangkara, pada hal nilai-nilai tersebut memiliki keterkaitan dengan kinerja individu. Sebagaimana dikemukakan oleh Darmawan (2013:144) bahwa budaya organisasi merupakan variabel yang mampu mempengaruhi kinerja individu. Dengan demikian maka dapat dikatakan bahwa, budaya organisasi mempunyai keterkaitan langsung dengan peningkatan kinerja pegawai.

Hubungan antara konsep pendidikan dan pelatihan maupun budaya organisasi terhadap keberhasilan pegawai dalam melaksanakan tugas dan tanggungjawabnya, perlu dikaji dilingkungan pegawai Rumah Sakit Bhayangara, karena secara fakta terlihat bahwa, pegawai yang memiliki jenjang pendidikan yang lebih tinggi kurang memiliki kemampuan intelektual sehingga dalam pelaksanaan tugas dan tanggungjawabnya tidak dapat dilaksanakan secara maksimal. Demikian juga terlihat bahwa, pengawai yang telah mendapatkan pelatihan 
tambahan masih kurang memberikan kontribusi dalam melaksanakan kegiatan kerja sehingga prestasi yang dicapai juga menjadi biasa-biasa saja. Demikian juga kepatuhan dan kedisiplinan pegawai dalam melaksanakan semua sistem tata nilai, kebiasaan maupun normanorma yang telah ditetapkan oleh Rumah Sakit Bhayangkara belum sepenuhnya dapat dijalankan oleh pegawai dengan baik sehingga berdampak terhadap pelaksanaan tugas menjdi tidak maksimal, yang pada akhirnya akan mempengaruhi terwujudnya kinerja organisasi sesuai dengan yang direncanakan. rencana pemecahan masalah disajikan dalambagian ini.

\section{TINJAUAN PUSTAKA}

\subsection{Pendidikan}

Pendidikan Nasional dibangun di atas landasan paradigma yang merujuk pada pemikiran, yang memandang bahwa pendidikan berhubungan dengan masyarakat dalam konteks perubahan sosial, tatanan ekonomi, politik dan negara, oleh karena pendidikan itu terjadi di masyarakat, dengan sumber daya masyarakat dan untuk masyarakat, maka pendidikan dituntut untuk mampu memperhitungkan dan melakukan antisipasi terhadap perkembangan sosial, ekonomi, politik dan kenegaraan.

Menurut Effendi (2005:72) pendidikan adalah "segalah usaha yang bertujuan mengembangkan sikap dan kepribadian, pengetahuan dan ketrampilan". Pendidikan sebagai tulang punggung kemajuan suatu negara, menentukan tinggi rendahnya derajat dan kedudukan bangsa. Pendidikan yang efektif melahirkan anak-anak bangsa yang cerdas, bermoral dan memiliki etos kerja dan inovasi karya yang tinggi. Pendidikan adalah suatu deskripsi dari pengetahuan, sikap, tindakan, penampilan dan sebagainya yang diharapkan akan memiliki sasaran pendidikan pada periode tertentu (Soekidjan, 1992).

\subsection{Pelatihan}

Pelatihan merupakan suatu usaha mengurangi atau menghilangkan terjadinya kesenjangan antara kemampuan pegawai dengan yang dikehendaki organisasi. Usaha tersebut dilakukan melalui peningkatan kemampuan kerja yang memiliki pegawai merupakan kekayaan organisasi yang paling berharga, karena dengan segala potensi yang dimilikinya, pegawai dapat terus dilatih dan dikembangkan, sehingga dapat lebih berkarya guna, prestasinya 
menjadi semakin optimal untuk mencapai tujuan organisasi.

Menurut Dessler (2006:280) mengatakan bahwa:" Pelatihan merupakan proses mengajar ketrampilan yang dibutuhkan karyawan untuk melakukan pekerjaannya”. Pelatihan menurut Mangkuprawira (2002:135) menjelaskan bahwa: "Pelatihan adalah sebuah proses mengajarkan pengetahuan dan keahlian tertentu serta sikap agar karyawan semakin terampil dan mampu melaksanakan tanggung jawab dengan semakin baik, sesuai dengan standar".

Menurut Effendi (2005:90) pelatihan adalah "proses pembelajaran yang lebih menekankan pada praktek dan pada teori yang dilakukan seseorang atau kelompok degan menggunakan pendekatan pelatihan untuk orang dewasa dan bertujuan meningatkan kemampuan dalam satu atau beberapa jenis ketrampilan tertentu ".

\subsection{Budaya Organisasi}

Organisasi dapat luwes dan juga dapat kaku, tidak bersahabat atau sprotif dan inovatif. Setiap organisasi memiliki karakter dan persaan yang unik diluar karakteristik strukturnya (Robbins, 1993). Wilkins (1983) mendefinisikan budaya sebagai sesuatu yang dianggap biasa dan dapat dibagi bersama yang diberikan orang terhadap lingkungan sosialnya. Lingkungan sosial dalam pengertian ini bisa dalam bentuk sebuah organisasi. Arti yang dapat dibagi bersama tersebut dinyatakan sebagai kebiasaan.

Pada beberapa literatur pemakaian istilah corporate culture bisa diganti dengan istilah organizational culture, kedua istilah ini memiliki pengertian yang sama. Budaya perusahaan (corporate culture) adalah aplikasi dari budaya organisasi (organizational culture) terhadap badan usaha (perusahaan), sehingga kedua istilah tersebut dapat digunakan secara bergantiaan. Karena itu kedua istilah tersebut dalam penelitian ini digunakan secara bersama dan keduanya memiliki pengertian yang sama.

Menurut Kreitner dan Kinicki (2005),budaya organisasi adalah satu wujud anggapan yang dimiliki, diterima secara implisit oleh kelompok dan menentukan bagaimana kelompok tersebut rasakan, pikirkan, dan bereaksi terhadap lingkungannya yang beraneka ragam. Mangkunegara (2005) menyatakan bahwa budaya organisasi adalah seperangkat asumsi atau sistem keyakinan, nilai-nilai, dan norma yang dikembangkan dalam organisasi yang dijadikan pedoman tingkah laku bagi anggota-anggotanya untuk mengatasi masalah adaptasi eksternal 
dan internal.

\subsection{Kinerja Pegawai}

Pada suatu organisasi, baik organisasi swasta (private sector) maupun organisasi pemerintah (public sector), kinerja atau prestasi kerja pegawai merupakan aspek yang sangat penting dalam upaya organisasi mencapai tujuan-tujuannya. Kinerja organisasi tidak dapat dilepaskan dari kinerja para pegawai dalam melaksanakan tugas dan pekerjaannya. Dengan demikian, maju atau tidaknya suatu organisasi sangat ditentukan oleh peran dan kualitas para pegawainya. Secara umum kinerja sering diartikan sebagai kemampuan untuk menghasilkan sesuatu hasil.

Kurniawan (2005) menyatakan bahwa kinerja merupakan penilaian atas kualitas pengelolaan dan kualitas pelaksanaan tugas atau operasi organisasi. Simamora (2004) menyatakan bahwa kinerja adalah tingkat kerja yang dicapai oleh seseorang dengan syaratsyarat yang telah ditentukan. Menurut Robbin (1997:26) bahwa "kinerja merupakan ukuran performance yang meliputi efektivitas dan effisiensi. Efektif berkaitan dengan pencapaian sasaran, sedang efisien adalah ratio antara output yang efektif dengan input yang diperlukan untuk mencapai sasaran".

Disamping teori tersebut Rivai (2004:15-16) menyebutkan : "kinerja adalah kesediaan seseorang atau kelompok orang untuk melakukan sesuatu kegiatan dan menyempurnakannya sesuai dengan tanggung jawabnya dengan hasil seperti yang diharapkan". "pada hakikatnya kinerja merupakan prestasi yang dicapai oleh seseorang dalam melaksanakan tugasnya atau pekerjaannya sesuai dengan standar dan kriteria yang ditetapkan untuk pekerjaan itu".Oleh karenanya, kinerja merupakan hal yang penting untuk dilakukan secara berkelanjutan dan memberikan umpan balik dalam upaya mencapai keberhasilan di masa mendatang.

\section{METODE PENELITIAN}

Pendekatan penelitian yang digunakan dalam penelitian ini adalah pendekatan kuantitatif. Populasi dalam penelitian ini adalah seluruh pegawai paramedis RS Bhayangkara Kendari, dimana berdasarkan totalnya yakni sebanyak 129 orang pegawai. Dimana besaran jumlah 
pegawai paramedis RS Bhayangkara Kendari yakni sebesar 129 orang pegawai merupakan para pegawai yang telah melakukan diklat (pelatihan). Alat analisis yang digunakan dalam penelitian ini adalah regresi linear berganda dan teknik pengumpulan data dalam penelitian ini menggunakan kuesioner.

\section{HASIL DAN PEMBAHASAN}

Pengolahan data dilakukan dengan menggunakan Software statistik SPSS kemudian dianalisis sesuai dengan parameter yang telah ditentukan dalam penelitian ini. Untuk lebih jelasnya output pengolahan data serta analisis statistiknya dapat dilihat pada tabel berikut :

Tabel 1

Hasil Estimasi Linear Berganda

Pengaruh Pendidikan, Pelatihan dan Budaya Organisasi

Terhadap Kinerja Pegawai di Rumah Sakit Bhayangkara Kendari

\begin{tabular}{|c|c|c|c|c|c|c|c|c|c|}
\hline \multirow[t]{2}{*}{ Model } & \multicolumn{9}{|c|}{$\begin{array}{l}\text { Unstandardized } \\
\text { Coefficients }\end{array}$} \\
\hline & B & $\begin{array}{l}\text { Std. } \\
\text { Eror }\end{array}$ & $\mathbf{T}$ & Sig & $\mathbf{R}$ & $\mathbf{R}^{2}$ & SEE & $\mathbf{F}$ & Sig \\
\hline (Constant) & & 0.411 & 3.146 & 0.002 & & & & & \\
\hline$X_{1}$ & 0,015 & 0.062 & 0.214 & 0.831 & 0.625 & 0.390 & 0.288 & 26.692 & 0.000 \\
\hline $\mathrm{X}_{2}$ & 0,478 & 0.095 & 5.667 & 0.000 & & & & & \\
\hline $\mathrm{X}_{3}$ & 0,213 & 0.063 & 2.509 & 0.013 & & & & & \\
\hline
\end{tabular}

Sumber Data : Hasil Olahan SPSS 2021

\subsection{Pendidikan Terhadap Kinerja Pegawai Rumah Sakit Bhayangkara Kendari}

Berdasarkan hasil penelitian yang telah dilakukan terkait pengaruh pendidikan terhadap kinerja pegawai Rumah Sakit Bhayangkara Kendari, ditemukan bahwa tidak terdapat pengaruh signifikan antara pendidikan pegawai terhadap kinerja pegawai atau dalam kata lain peningkatan kinerja pegawai tidak didasari atas adanya peran pendidikan sebagai salah satu faktor yang menunjang kinerja pegawai Rumah Sakit Bhayangkara Kendari.

Sebuah lembaga atau organisasi, baik bersifat profit maupun nonprofit, akan memiliki ketergantungan pada aspek sumber daya manusia. Sumber daya manusia memiliki faktor kendali yang dapat menentukan keberlangsungan sebuah perusahaan (Engel, 2001). Faktor sumber daya manusia dalam hal kualitasnya akan menentukan kualitas organisasi tersebut yang nantinya berpengaruh pada kelangsungan hidupnya. Salah satu hal yang dapat dijadikan parameter tentang kualitas kerja sumber daya manusia adalah tingkat prestasi kerja yang ada 
pada sumber daya manusia tersebut (Swastha, 2001).

Secara logika dapat dikatakan bahwa semakin tinggi prestasi kerja seorang pegawai maka dapat dikatakan bahwa semakin tinggi pula kualitas pegawai tersebut. Prestasi kerja pegawai tidak akan timbul begitu saja, melainkan membutuhkan suatu pendekatan yang intensif untuk memahami faktor-faktor yang dapat menumbuhkan prestasi kerja pegawai. Tinggi rendahnya tingkat prestasi seorang pegawai sebuah perusahaan dapat dipengaruhi oleh beberapa faktor (Alma, 2000). Faktor yang dimaksudkan antara lain adalah kemampuan karyawan untuk selalu mengikuti perubahan yakni pendidikan dari pegawai itu sendiri.

Hasil penelitian ini sekaligus menolak teori yakni mengenai adanya pengaruh antara pendidikan dengan kinerja pegawai. Sebagaimana yang dikemukakan oleh Simamora (2004) bahwa penyelenggaraan pendidikan merupakan salah satu upaya untuk meningkatkan kualitas sumber daya manusia sesuai dengan kebutuhan pekerjaan. Lebih lanjut diuraikan bahwa pendidikan dan pelatihan pegawai adalah suatu persyaratan pekerjaan yang dapat ditentukan dalam hubungannya dengan keahlian dan pengetahuan berdasarkan aktivitas yang sesungguhnya dilaksanakan pada pekerjaan. Sehingga dengan adanya pendidikan maka pelaksanaan kerja pegawai akan semakin baik dalam hal ini semakin baiknya kinerja pegawai dalam bekerja.

Adanya pengaruh yang tidak signifikan antara pendidikan dan kinerja pegawai Rumah Sakit Bhayangkara Kendari, dimungkinkan karena adanya peran faktor-faktor lain diluar dari pendidikan yang sekiranya lebih berpengaruh pada kinerja. Seperti halnya tingkat pengalaman kerja dari pegawai itu sendiri, dimana para pegawai yang dimaksud dalam penelitian ini adalah pegawai paramedik yang berdasarkan konteksnya bekerja dalam menangani pasien, sehingga pendidikan bukan merupakan salah satu penunjang utama dalam meningkatkan kinerja para pegawai tersebut, akan tetapi lebih pada pengalaman-pengalaman kerja yang dimiliki oleh para pegawai itu sendiri yang dapat menunjang pada kinerja pegawai.

Semakin banyaknya pengalaman yang dimiliki oleh seorang pegawai maka akan semakin mudahnya pegawai tersebut dalam menangani masalah-masalah dalam Rumah Sakit Bhayangkara, khususnya terkait masalah-masalah dari setiap pasien. Sehingga berdasarkan hal ini pula dimungkinkan pendidikan tidak berpengaruh signifikan dikarenakan adanya faktor pengalaman sebagai faktor dominan dalam pengaruhnya terhadap kinerja pegawai. 
Hasil penelitian ini sejalan dengan uraian yang dikemukakan oleh Widodo (2013) yang mengemukakan bahwa adanya pengaruh yang tidak signifikan antara pendidikan dengan kinerja pegawai dikarenakan adanya faktor pengalaman kerja, masa kerja, jenis pekerjaan yang bersifat berulang dan memiliki prosedur yang jelas sehingga mengakibatkan pendidikan kurang berpengaruh terhadap kinerja pegawai.

\subsection{Pelatihan Terhadap Kinerja Pegawai Rumah Sakit Bhayangkara Kendari}

Berdasarkan hasil penelitian yang telah dilakukan yakni terkait pengaruh pelatihan terhadap kinerja pegawai Rumah Sakit Bhayangkara Kendari, ditemukan bahwa terdapat pengaruh positif signifikan antara pelatihan pegawai terhadap kinerja pegawai di Rumah Sakit Bhayangkara Kendari. Hal ini berarti bahwa pelatihan yang ditinjau dari manfaat hasil pelatihan kerja, transfer of training, tambahan pengetahuan dan keterampilan, meningkatkan motivasi dalam bekerja, penyebaran hasil pelatihan dan penerapan hasil pelatihan, pada dasarnya mempunyai peranan dalam meningkatkan kinerja pegawai. Dengan demikian bahwa setiap adanya peningkatan pelatihan pada pegawai, maka kinerja pegawai akan ikut mengalami peningkatan sejalan dengan peningkatan dari hasil pelatihan. Sumber daya yang paling penting dalam setiap organisasi adalah sumber daya manusia. Peranan sumber daya manusia dalam organisasi sangat penting karena sebagai penggerak utama dari seluruh kegiatan atau aktivitas dalam mencapai tujuan sekaligus untuk memperoleh keuntungan maupun untuk mempertahankan kelangsungan hidup organisasi. Berhasil tidaknya suatu organisasi dalam mempertahankan eksistensi organisasi dimulai dari usaha mengengelola sumber daya manusia, khususnya dalam meningkatkan efektivitas dan efisiensi kerja secara maksimal.

Kemampuan pegawai dalam bekerja untuk mencapai tujuan organisasi/instansi dipengaruhi oleh berbagai faktor secara internal, salah satu-nya adalah melalui pelatihan dimana melalui program tersebut diharapkan organisasi/instansi dapat mempertahankan pegawai yang berpotensi dan berkualitas.

Lebih lanjut diuraikan bahwa adanya hubungan positif signifikan antara pelatihan dan kinerja pegawai didukung dengan hasil dari identitas responden yang menyatakan bahwa para pegawai Rumah Sakit Bhayangkara secara rata-rata mendapatkan pelatihan sebanyak 4 kali 
selama masa kerjanya, dan rata-rata pula yang mendapatkan pelatihan sebanyak 4 kali adalah para pegawai dengan usia berkisar antara 20 - 30 tahun. Sehingga berdasarkan hal ini dapat disimpulkan bahwa semakin seringnya para pegawai dalam mengikuti berbagai pelatihan maka kinerja pegawai di Rumah Sakit Bhayangkara akan semakin jauh lebih baik.

Hasil penelitian ini sejalan dengan teori yang dikemukakan oleh Amstrong (1998) bahwa guna memperbaiki kualitas pemikiran para tenaga kerja atau pegawai dalam suatu organisasi, baik publik maupun usaha bisnis maka diperlukan adanya pelatihan (training) dan pengembangan pegawai. Pelatihan adalah sama dengan pengembangan pegawai yaitu proses peningkatan keterampilan kerja tehnis maupun keterampilan manajerial yang berorientasi secara teori dan praktek dalam pekerjaan, selanjutnya yang bersangkutan setelah mengikuti pelatihan, maka meningkat pula motivasi kerjanya karena mampu melaksanakan pekerjaan.

Pelatihan sangatlah diperlukan oleh pegawai atau organisasi dikarenakan pelatihan sangat berguna dan bermafaat besar dalam menunjang pekerjaan maupun tujuan organisasi. Hal ini sejalan dengan pandangan Ronald (2000:348) yang menyatakan bahwa, pelatihan merupakan investasi langsung maupun tidak langsung dari organisasi sebagai pengirim peserta dan sangat bermanfaat bagi peserta itu sendiri maupun unit kerjanya (organisasi).

Adanya pegawai yang terlatih tersebut, maka organisasi memiliki sumber daya manusia yang mempunyai kompetensi yang berkualitas untuk diimplementasikan dalam lingungan kerjanya sehingga dapat memberi kontirbusi dalam meningkatkan kinerja pribadinya maupun kinerja organisasi kearah yang lebih baik, oleh karena itu diperlukan pula adanya dukungan lingkungan internal organisasi dan budaya kerja yang dapat memberikan motivasi pegawai yang terlatih agar dapat menyalurkan keterampilannya dilingkungan kerjanya sehingga pengetahuan dan keterampilan yang dimiliki dapat memberi pembelajaran pada rekan sekerja dan pada akhirnya akan berdampak pada peningkatan kinerja pegawai maupun kinerja organisasi.

Hal ini telah dibuktikan oleh Edi, Siswidiyanto dan Sukantor (2010) dan Suardi, Anto dan Suharsil (2014) bahwa, training (pelatihan) memiliki pengaruh yang positif dan signifikan terhadap kinerja pegawai dan lebih lanjut dikemukakan bahwa pelatihan yang selama ini diadakan mampu mengubah perilaku, sehingga tingkat kinerjanya meningkat. 
Menurut Simamora (2004) mengemukakan bahwa pendidikan dan pelatihan pegawai adalah suatu persyaratan pekerjaan yang dapat ditentukan dalam hubungannya dengan keahlian dan pengetahuan berdasarkan aktivitas yang sesungguhnya dilaksanakan pada pekerjaan. Lebih lanjut dikemukakan pula oleh Irianto (2001) bahwa nilai-nilai seseorang dapat dipupuk melalui program pendidikan, pengembangan dan pelatihan yang berorientasi pada tuntutan kerja aktual dengan menekankan pada pengembangan skill, knowledge dan ability yang secara signifikan akan memberi standar dalam sistem dan proses kerja yang diterapkan.

Hal serupa dikemukakan pula oleh Anwar, 2011 bahwa berdasarkan pendapat Ernest J. Mc. Cormick tersebut suatu organisasi perlu melibatkan sumberdaya (pegawainya) pada aktivitas pelatihan, hanya jika hal ini merupakan keputusan terbaik dari manajer. Pelatihan diharapkan dapat mencapai hasil lain daripada memodifikasi perilaku pegawai. Hal ini juga mendukung organisasi dan tujuan organisasi, seperti peningkatan kualitas pegawai pada khususnya.

\subsection{Budaya Organisasi Terhadap Kinerja Pegawai Rumah Sakit Bhayangkara Kendari}

Berdasarkan hasil penelitian yang telah dilakukan terkait pengaruh budaya organisasi terhadap kinerja pegawai di Rumah Sakit Bhayangkara Kendari, ditemukan bahwa terdapat pengaruh positif signifikan antara budaya organisasi terhadap kinerja pegawai di Rumah Sakit Bhayangkara Kendari. Hal ini berarti bahwa budaya organisasi yang ditinjau dari pemberian apresiasi positif, tuntutan untuk bekerja secara terinci dan tuntas, orientasi hasil kerja yang maksimal, penghargaan hasil kerja organisasi, orientasi pada kepentingan dan keputusan tim kerja, keagresifan dalam melaksanakan tugas dan pelaksanaan tugas dan pekerjaan yang mengacu pada stabilits dalam bekerja, pada dasarnya mempunyai peranan dalam meningkatkan kinerja pegawai. Dengan demikian bahwa setiap adanya peningkatan budaya organisasi akan berdampak terhadap peningkatan kinerja pegawai itu sendiri.

Budaya pada umumnya dikaitkan dengan tradisi dan cara berperilaku di antara negara atau daerah yang berbeda. Akhirnya berkembang pendapat bahwa hal yang sama dapat terjadi diantara organisasi yang berbeda. Setiap organisasi memiliki sendiri cara mengerjakan sesuatu, tipe keperibadian berbeda yang cenderung melakukan hal-hal baik, dan bentuk 
hubungan yang berbeda.

Dari hasil analisis data menunjukkan bahwa untuk keberhasilan organisasi dalam membangun budaya organisasi adalah harus berkesinambungan dan memiliki hubungan jangka panjang antara pegawai dengan organisasi. Salah satu faktor yang berpengaruh besar terhadap peningkatan kinerja pegawai adalah budaya organisasi. Budaya organisasi mempunyai peran penting dalam menentukan pertumbuhan organisasi. Organisasi dapat tumbuh dan berkembang karena budaya organisasi yang terdapat di dalamnya mampu merangsang untuk semangat kerja sumber daya manusia diorganisasi itu sendiri, sehingga dapat berakibat pada peningkatan kinerja organisasi.

Adanya hubungan positif signifikan antara budaya organisasi terhadap kinerja pegawai, dimungkinkan karena adanya sistematika budaya organisasi yang telah dibangun dengan baik dalam jangka waktu lama pada Rumah Sakit Bhayangkara Kendari. Terlebih lagi hal ini didukung dengan para pegawai yang masih berusia produktif yakni berkisar antara usia 20 30 tahun, sehingga pada usia ini pegawai memiliki kemudahan dalam menyesuaiakan diri dalam budaya organisasi yang telah ada dan juga memiliki motivasi yang tinggi dalam bekerja sehingga berdampak langsung pada kinerja pegawai itu sendiri.

Kinerja (performance) sebenarnya merupakan fungsi dari kemampuan kerja, kemampuan tanpa ada dukungan budaya organisasi yang baik tidak akan menghasilkan sesuatu, akan tetapi walaupun kemampuan berkurang kalau didorong dengan budaya organisasi yang baik akan menghasilkan sesuatu yang lebih baik dan berguna, khususnya dalam meningkatkan kinerja pegawai dan kinerja organisasi.

Hasil penelitian ini mendukung teori dari Robbins (2001 : 259) yang memberikan penekanan bahwa seharusnya tidak melewaktkan pengaruh sosialisasi budaya organisasi pada kinerja pegawai, karena kinerja seorang pegawai tergantung pada tingkat pengetahuannya akan apa yang harus atau tidak harus ia kerjakan. Lebih lanjut diuraikan oelh Priasmono dalam Syarwani dan Priyohadi (2001) mengemukakan bahwa ada banyak keuntungan bila perusahaan memiliki budaya yang kuat, adaptif dan kompetitif antara lain meningkatkan produktivitas dan kreatifitas, mengembangkan kualitas barang dan jasa serta memotivasi pegawai untuk mencapai kinerja yang tinggi. 
Pegawai yang sudah memahami keseluruhan nilai-nilai organisasi akan menjadikan nilainilai tersebut sebagai suatu kepribadian organisasi. Nilai dan keyakinan tersebut akan diwujudkan menjadi suatu perilaku keseharian mereka dalam bekerja sehingga akan menjadi kinerja individual. Thoyib (2007) mengatakan bahwa kinerja yang tinggi yang adap individu dalam organisasi menunjukkan bahwa apa yang dilakukan oleh individu adalah sesuai yang diprogramkan dalam organisasi. Dengan demikian kinerja yang tinggi, tentunya ada budaya organisasi yang baik. Abdullah (2007) menyatakan bahwa budaya organisasi tdak bisa dipisahkan dari kinerja. Semakiin kuat budaya organisasi, maka makin kuat pula dorongan untuk berprestasi.

Budaya organisasi berdampak pada kinerja jangka panjang organisasi, bahkan mungkin merupakan faktor penting dalam menentukan keberhasilan atau kegagalan organisasi. Meskipun tidak mudah untuk berubah, budaya organisasi dapat meningkatkan kinerja sehingga produktivitas organisasi meningkat. Menurut Wibowo (2012) bahwa organisasi dengan budaya yang kuat dan positif akan memungkinkan orang merasa termotivasi untuk berkembang, belajar dan memperbaiki diri. Jika orang bekerja dalam organisasi yang dikelola dengan baik akan mempunyai motivasi dan kepuasan yang lebih tinggi serta pada akhirnya akan berdampak pada peningkatan kinerja pegawai.

Selanjutnya diurakan pula oleh Schein (1992) mengatakan bahwa, budaya organisasi adalah pola asumsi-asumsi dasar bentukan, temuan atau pengembangan oleh suatu kelompok orang yang telah bekerja dengan cukup baik untuk mengatasi masalah-masalah adaptasi eksternal maupun integrasi internal, sehingga perlu diajarkan juga kepada anggota baru sebagai cara yang benar dalam memandang, berpikir dan merasa tentang masalah-masalah yang dihadapinya. Jadi, budaya organisasi merupakan kerangka kerja yang menjadi pedoman tingkah laku sehari-hari untuk mencapai tujuan organisasi. Budaya organisasi mampu merubah sikap dan perilaku sumber daya manusia untuk mencapai produktivitas kerja yang lebih baik dalam menghadapi tantangan masa depan (Teguh Sudarto, 2004 : 5). Sedangkan Kotter dan Heskett (1992) mengatakan bahwa budaya organisasi mempunyai kekuatan yang penuh, berpengaruh pada individu dan kinerjanya bahkan lingkungan kerjanya, dengan demikian maka dapat dikatakan bahwa budaya organisasi mempunyai kontribusi terhadap sikap dan perilaku individu, khususnya perilaku dari setiap pegawai. 


\subsection{Pendidikan, Pelatihan dan Budaya Organisasi Terhadap Kinerja Pegawai Rumah Sakit Bhayangkara Kendari}

Berdasarkan hasil penelitian yang telah dilakukan yakni terkait pengaruh pendidikan, pelatihan dan budaya organisasi terhadap kinerja pegawai Rumah Sakit Bhayangkara Kendari menunjukkan bahwa secara simultan terdapat adanya pengaruh positif signifikan antara pendidikan, pelatihan dan budaya organisasi terhadap kinerja. Hal ini sejalan dengan hasil uji simultan antar pendidikan, pelatihan dan budaya organisasi terhadap kinerja pegawai yang berdasarkan hasil ujinya memiliki nilai Signifikan berada dibawah $\alpha=0,05$.

Sumber daya manusia (man) merupakan salah satu komponen yang ada dalam organisasi selain machine, money, materials, methods, and market. Menurut Notoatmodjo (2003, h. 2), "Sebuah instansi harus didukung sumber daya manusia yang cakap karena sumber daya manusia sangat berperan dalam menjalankan usaha atau kegiatan di dalam instansi tersebut. "Berdasarkan pendapat tersebut sumber daya manusia merupakan hal yang terpenting dalam suatu organisasi karena perannya sebagai subyek pelaksana kebijakan dan kegiatan operasional suatu organisasi. Oleh karena itu organisasi membutuhkan sumber daya manusia dalam hal ini yaitu pegawai yang mempunyai kinerja (jobperformance) yang tinggi. Di mana kinerja pegawai yang tinggi atau baik dapat dijadikan salah satu faktor dasar tolak ukur keberhasilan suatu organisasi dalam mencapai tujuannya.

Kinerja dalam suatu organisasi pada dasarnya dapat dipengaruhi oleh beberapa faktorfaktor salah satunya adalah melalui faktor personal/individual yakni melalui peran pendidikan dan pelatihan serta melalui faktor sistem yakni melalui peran budaya organisasi.

Hasil ini sejalan dengan uraian yang dikemukakan oleh Wardono (2012) bahwa salah satu instrument dalam pengembangan sumber daya aparatur atau peningkatan kualitas aparatur adalah melalui pendidikan dan pelatihan. Melalui pendidikan dan pelatihan ini tujuan yang hendak dicapai pada dasarnya tersampaikan. Seperti halnya tujuan akan peningkatan kesetiaan dan ketaatan kepada Pancasila dan Undang-Undang Dasar 1945, peningkatan pengetahuan, keahlian, keterampilan dan sikap untuk dapat melaksanakan tugas jabatan secara professional, menciptakan aparatur yang mampu berperan sebagai pembaharu dan perekat persatuan dan kesatuan bangsa, memantapkan sikap dan semangat kepribadian yang berorientasi pada pelayanan, pengayoman dan pemberdayaan masyarakat dan menciptakan kesamaan visi dan 
dinamika pola piker dalam melaksanakan tugas pemerintahan umum demi terwujudnya pemerintahan yang baik.

Hal serupa dikemukakan pula oleh Zibans (1997) bahwa pendidikan dan pelatihan merupakan proses yang berlanjut dan bukan proses sesaat saja terutama disaat perkembangan teknologi dan pengetahuan berkembang pesat seperti saat ini, peran pendidikan dan pelatihan sangat besar peranannya untuk membekali pegawai agar lebih kreatif dalam mencapai tujuan perusahaan secara efektif dan efisien. Sementara secara umum tujuan pelaksanaan pendidikan dan pelatihan adalah memperbaiki efektifitas dan efisiensi kerja pegawai dalam melaksanakan dan mencapai sasaran program-program kerja yang telah ditetapkan. Semakin baik program pendidikan dan pelatihan yang dilakukan oleh pengelola organisasi maka semakin terampil pegawai dalam menyelesaikan pekerjaan.

Hal ini sejalan dengan Teguh (2004) bahwa budaya organisasi merupakan kerangka kerja yang menjadi pedoman tingkah laku sehari-hari untuk mencapai tujuan organisasi. Budaya organisasi mampu merubah sikap dan perilaku sumber daya manusia untuk mencapai produktivitas kerja yang lebih baik dalam menghadapi tantangan masa depan. Sejalan dengan uraian tersebut, dikemukakan pula oleh Kotter dan Heskett (1992) mengatakan bahwa budaya organisasi mempunyai kekuatan yang penuh, berpengaruh pada individu dan kinerjanya bahkan lingkungan kerjanya, dengan demikian maka dapat dikatakan bahwa budaya organisasi mempunyai kontribusi terhadap sikap dan perilaku individu, khususnya perilaku dari setiap pegawai.

\section{KESIMPULAN}

Ditemukan bahwa adanya pengaruh positif signifikan antara pelatihan dan budaya organisasi terhadap kinerja pegawai Rumah Sakit Bhayangkara Kendari. Selanjutnya untuk pendidikan ditemukan bahwa terdapat pengaruh positif tidak signifikan terhadap kinerja pegawai. Hal ini berarti adanya peran faktor-faktor lain diluar dari pendidikan yang sekiranya lebih berpengaruh pada kinerja, seperti halnya tingkat pengalaman-pengalaman kerja dari pegawai yang mampu menunjang kinerja pegawai. Hubungan positif signifikan antara pelatihan terhadap kinerja pegawai, berarti bahwa kegiatan pelatihan baik itu secara spesifik maupun praktis mempunyai peranan yang berarti dalam meningkatkan kinerja pegawai Rumah Sakit 
Published online in http://e-journal.uniflor.ac.id/index.php/analisis

Bhayangkara Kendari. Hubungan positif signifikan antara budaya organisasi terhadap kinerja pegawai, berarti bahwa budaya organisasi yang ditinjau dari inovasi dan pengambil risiko, perhatian terhadap detail, orientasi hasil, orientasi orang, orientasi tim, keagrefisan dan stabilitas mempunyai peranan yang berarti dalam meningkatkan kinerja pegawai Rumah Sakit Bhayangkara Kendari. Selanjutnya untuk pendidikan ditemukan bahwa terdapat pengaruh positif tidak signifikan terhadap kinerja pegawai. Hal ini berarti adanya peran faktor-faktor lain diluar dari pendidikan yang sekiranya lebih berpengaruh pada kinerja, seperti halnya tingkat pengalamanpengalaman kerja dari pegawai yang mampu menunjang kinerja pegawai.

\section{REFERENSI}

Agusta Leonando \& Sutanto Eddy Madiono. 2013. Pengaruh pelatihan dan motivasi kerja terhadap kinerja karyawan CV Haragon Surabaya, AGORA Vol. 1, No. 3.

Amin Anam, Rashid Saeed, Rab Nawaz Lodhi, Mizna, Simra, Anam Iqbal and Rida-eTehreem. 2013. The Impact of Employees Training On the Job Performance in Education Sector of Pakistan, Middle-East Journal of Scientific Research 17 (9): 1273-1278, 2013 ISSN 1990-9233.

Arnone, Laurent, Claire Dupont and Severine Spataro. 2005. Human Resources Management and Labor Demand Dinamics In Belgium. International Journal of Manpower, Volume 26, No 7/8, pp : 724-743.

Becker, G.S. (1962). Investment in human capital: a theoretical analysis. Journal of political economy, Vol. 70, Issue 5, p. 9-49.

Benardin, H. John and Joce E. A. Russel (1998). Human Resources Management. New York.

Blundell, R.; et al. (1999). Human capital investment: the returns from education and training to the individual, the firm and the economy. Fiscal studies, Vol. 20, No 1, p. 1-23.

Churchill, G.A.; Ford, N.M.; and Walker, O.C. Jr (1987), Sales Force Management- Planning, Implementation and Control, Second Edition, Irwin Inc.

Davis, K dan J. W. Newstrom. 1994. Perilaku dalam Organisasi. Erlangga, Jakarta.

Denison, Daniel R. 1990. Corporate Culture and Organizational Efektiveness. New York: John Wiley \& Sons.

Desles, Garry. 2006. Manajemen Personalia. Alih Bahasa, Agus Dharma. Jakarta : Erlangga.

Dharma, Agus. 2003. Manajemen Perilaku Organisasi Pendayagunaan Sumber Daya Manusia, Jakarta: Gelora Aksara Pratama

Diab, Salah M \& Ajlouni, T Musa. 2015. The Influence of Training on Employee's Performance, Organizational Commitment, and Quality of Medical Services at Jordanian Private Hospitals, International Journal of Business and Management; Vol. 10, No. 2; 2015 ISSN 1833-3850 E-ISSN 1833-8119 Published by Canadian Center of Science and Education

Dora, \& Sabahg. (2008). Human Resource Management. Dar Wael for publication, Amman, Jordan.

Efendi, Agus. 2005. Revolusi Kecerdasan Abad 21. Bandung: Alfabeta. 
Published online in http://e-journal.uniflor.ac.id/index.php/analisis

Emzir. 2008. Metodologi Penelitian Pendidikan Kuantitatif \& Kualitatif, Jakarta: Raja Grafindo Persada.Flippo, E.B. 1984. Personnel Management, Singapore :McGraw Hill.

Ghozali, Imam. 2006. Aplikasi Analisis Multivariate Dengan Program SPSS. Semarang: Badan Penerbit Universitas Diponegoro.

Gibson, J. L., Ivancovich J. M., Donnelly, J. H. 1997. Organisasi : Perilaku, Struktur, Proses. Alih Bahasa Nunuk Adiarni, Edisi Kedelapan, Jilid II, Binarupa Aksara, Jakarta.

Gomes, F.C. 2001. Manajemen Sumber Daya Manusia, Yogyakarta: Andi Offset.

Gujarati, Damodar, 1997. Ekonometrika Dasar. Erlangga. Jakarta

Harrison, Roger \& Herb Stokes, 1992. "Diagnosing Oragnizational culture”. Prieffer \& Company, California, USA

Hasanah. 2010. Pengaruh pendidikan latihan (diklat) kepemimpinan guru dan iklim kerja terhadap kinerja guru sekolah dasar se Kecamatan Babakancikao Kabupaten Purwakarta, Jurnal Penelitian Pendidikan Vol. 11, No. 2.

Hasibuan, Malayu S.P. 2003. Manajemen Sumber Daya Manusia (Edisi Revisi), Penerbit Bumi Aksara, Jakarta.

Hasbullah. 2009. Dasar-Dasar Ilmu Pendidikan. Jakarta: PT. Raja Grafindo Persada.

Hasnizah, Binti Hamidun. 2009. The Influence of Training on Employee's Work Commitment and Performance, Thesis, University of Malaya, in partial fulfillment of the requirements for the Degree of Master Business Administration.

Idris, Zahari. 1994. Strategi Pendidikan Nasional, Jakarta, Ghalia.

Irianto. J, 2001, Tema-tema Pokok Manajemen Sumber Daya Manusia, Insan Cendikia, Surabaya.

Jayawarna, Allan Machperson dan Allison Wilson. 2007. Trainning Commitment and Performance in Manufacturing SMEs. Journal of Small Business and Enterprise Development, Volume 14 Number 2 pp. 321 - 338.

Kepha Ombui, Kagiri, Assumptah, Omoke, Dismas. 2012. The influence of training and development on the performance of employees in research institutes in Kenya. International Journal of Science and Research (IJSR) ISSN (Online): 2319-7064.

Kotter, John P. \& James L. Heskett. 1992. Corporate Culture dan Performance Free Press, New York, NY.

Kreitner, Robert dan Angelo Kinichi, 2005, Perilaku Organisasi: Organizational Behavior, Jakarta: Salemba Empat.

Lettmayr, Cristian F \& Nehls, Hermann. 2011. The impact of vocational education and training on company performance, Cedefop, Luxembourg: Publications Office of the European Union.

Leiden, Robert. 2001. Managing Individual Performance In Works Groups. Journal Human Resources Management Vol 40.

Mangkuprawira, 2002, Manajemen Sumber Daya Manusia Strategik, Penerbit Ghalia. Indonesia, Jakarta.

Mangkuprawira, Sjafri \& Hubeis ,Aida Vitayala. 2007. Manajemen Mutu. Sumber Daya Manusia, Ghalia Indonesia. Bogor. 
Published online in http://e-journal.uniflor.ac.id/index.php/analisis

Mangkunegara AA Anwar Prabu. 2006, Manajemen SDM Perusahaan. Bandung, PT. Remaja Rosdakarya.

Mathis, R.L dan Jackson, J.H. 2001. Manajemen Sumber Daya Manusia, Terjemahan. Edisi Pertama. Jakarta: PT. Salemba Emban Patria.

Mincer, J. 1962. On-the-job training: costs, returns and some implications. Journal of political economy, Vol. 70, No 5, p. 50-79.

Mondy, R. W. dan Noe R. M. 1996. Personnel : The Management of Human Resources, Allyn and Bacon Inc., Boston.

Musanef, 1994, Manajemen Kepegawaian di Indonesia, Gunung Agung, Jakarta.

Nitisemito, Alex S. 1994. Manajemen Personalia, Galia Indonesia, Jakarta.

Notoatmodjo, Soekidjo. 2003. Pendidikan dan Perilaku Kesehatan. Jakarta: Rineka Cipta.

Oktaviani Harmusa. 2014. Pengaruh Lingkungan Kerja dan Budaya Organisasi Terhadap Kinerja Karyawan Pada Koperasi Sumber Rezeki Rembang, Jurnal, Universitas Diponegoro, Semarang.

Pakpahan Edi Saputra, Siswidiyanto, Sukanto. 2014. Pengaruh Pendidikan Dan Pelatihan Terhadap Kinerja Pegawai (Studi Pada Badan Kepegawaian Daerah Kota Malang), Jurnal Administrasi Publik (JAP), Vol. 2, No. 1.

Rachmawati, Ike Kusdyah. 2008. Manajemen Sumber Daya Manusia, Penerbit. ANDI, Yogyakarta.

Pane Jagarine, dan Astuti Sih Darmi. 2009. Pengaruh Budaya Organisasi, Kepemimpinan Transformasional dan Kompensasi Terhadap Kinerja Karyawan, Jurnal Telaah Manajemen Edisi 1.

Pratama Yoga. 2012. Pengaruh Budaya Organisasi Terhadap Kinerja Pegawai Pada Kantor Kecamatan Nanggung Kabupaten Bogor, Jurnal, Universitas Indonesia.

Raymond, A., Noe., John, R., Hollenbeck., Barry, G. \& Patrick, M.W. 2008. Human Resources Management : Gaining A Competitive Advantage, 6th Edition,McGraw-Hill/Irwin

Rivai, Veithzal. 2004. Manajemen Sumber Daya Manusia untuk Perusahaan dari Teori ke Praktik. PT Rajagrafindo Persada, Jakarta.

Robbins, Stephen P. dan Judge, Timothy A. 2006. Perilaku Organisasi Edisi ke-10, Jakarta: Salemba Empat.

Robbins, Stephen P. 1997. Perilaku Organisasi, PT. Prenhallindo, Jakarta.

Santoso, Singgih. 2004. Buku Latihan SPSS Statistik Parametrik, PT. Elex Media Komputindo, Jakarta.

Saydam, Gouzali. 1997. Kamus Istilah Kepegawaian, Pustaka Sinar Harapan, Jakarta.

Scott-Ladd, Brenda, Anthony Travaglione and Verena Marshall. 2006. Leadership and Organization Development Journal. Volume 27. No. 5, pp: 399-414.

Schein, E.H. 1992. Organizational Culture and Leadership, 2nd ed, San Francisco, CA: Jossey Bass.

Siswanto, Bedjo Sastrohadiwiryo. 2002. Manajemen Tenaga Kerja Indonesia: Pendekatan Administratif dan Operasional. Jakarta Bumi: Aksara.

Simamora, Henry. 1997. Manajemen Sumber Daya Manusia. Edisi Kedua.STIE : YKPN

Simamora, Henry. (2004). Manajemen Sumber Daya Manusia Edisi III. Jakarta : STIE YKPN. 
Published online in http://e-journal.uniflor.ac.id/index.php/analisis

Soekidjan. 2009. Manjaemen Sumber Daya Manusia. Jakarta:Bumi Aksara Suardi Yakub, Anto Tulim, Suharsil. 2014. Jurnal SAINTIKOM Vol. 13, No.3.

Solimun. 2010. Pemodelan Persamaan Struktural Pendekatan PLS. Brawijaya. Malang.

Sugiyono. 1999. Statistik Non-parametrik untuk Penelitian, Alfabeta, Bandung.

Supranto, J. M.A. 1997. Metode Riset, Aplikasinya dalam Pemasaran. Lembaga Penerbit F.E. Universitas Indonesia, Jakarta.

Suwanto, H. dan Donni Juni Priansa. (2011). Manajemen SDM Dalam Organisasi Publik dan Bisnis. Bandung:Alfabeta.

Suradji. 2006. Manajemen Kepegawaian Negara, Modul Pendidikan dan Pelatihan Prajabatan Golongan III, Lembaga Administrasi Negara RI.

Tampubolon, Manahan P. 2008. Perilaku Keorganisasian. Bogor: Ghalia Indonesia

Taufiq Lazuardy, Yuwaldi., Away, Shabri, Abd. Majid, 2014. Pengaruh Kepemimpinan dan Budaya Organisasi Terhadap Kepuasan Kerja Serta Dampaknya Pada Kinerja Pegawai Negeri Sipil SETDAKAB Aceh Barat Daya”. Jurnal Manajemen Pascasarjana Universitas Syiah Kuala. Vol. 3, No. 2 Mei.

Thomas, W.H. \& Feldman, Daniel C. 2009. How Broadly Does Education Contribute To Job Performance, Journal Personnel Psychology 2009, 62, 89-134.

Vonderembse, Qingyu Znang Mark A, and Jeen Sul Lim. 2003. Manufacturing FlexibilityDefining and Analyzing Relationship Among Competence, Capability and Customer Satisfaction. Journal of Operation Management, Vol 21, No. 173-191.

Zibarus, 1997. Usahawan. Jakarta. Penerbit Binarupa Aksara 